\section{『再生可能エネルギーの発電予測と システム技術』特集}

論文誌 B (電力・エネルギ一部門誌) では，平成 26 年 6 月号に「再生可能エネルギーの発電予測とシステム技術」 特集を企画しています。

将来のエネルギーネットワークにおいて再生可能エネル ギーの大量導入時には, 各種制御, システム系において予 測技術が必要となる。例えば，電力系統においては，需給 バランスの観点では, 系統大の風力発電, 太陽光発電の出 力把握や予測が必要となる。また, HEMS, BEMS などの エネルギーマネージメント，スマートコミュニティや離島 マイクログリッドなどを想定した場合には, ローカル・ー 定のエリアでの把握・予測技術も重要となる。これらの実 現には，横断的な技術分野の連携が必要不可欠である。

本特集では，水力発電，風力発電，太陽光発電，気象予測 に対して，推定・把握技術（リアルタイム, Nowcasting） および短時間，長期予測技術 (Forecasting), さらに，こ れら技術を利用した制御・システム技術に関して広く論文 を募集します。

（想定される論文内容）

・発電予測に利用される気象予測技術, 気象関係計測 · 観測技術

・統計モデル, 数理モデル, 画像処理技術を利用した発
電推定・把握, 予測技術

- 発電推定・把握, 発電予測技術を利用した制御技術,

実証研究, 予測等の有効性評価, 必要予測仕様の評価 に関する論文を広く募集します。

掲載 号平成 26 年 6 月号

投稿締切平成 25 年 8 月 30 日（金）

電子投稿・査読システムの「論文投稿」画面に おいて,「再生可能エネルギーの発電予測とシ ステム技術」特集を選択してください。

投稿方法 投稿は電子投稿・査読システムで受付けます。 http://www2.iee.or.jp/ver2/honbu/14-magazine/ index030.html より電子投稿してください。

電子投稿・査読システムの詳細につきまして は, 論文誌 B の 2007 年 11 月号をご覧くださ い。また, 電力・エネルギー部門の Web ページ に，投稿のための簡易マニュアルがあります。 http://www2.iee.or.jp/ver2/pes/13-magazine/ index040.html

問合せ先 新エネルギー環境技術委員会

大関 崇 独立行政法人 産業技術総合研究所 太陽光発電工学研究センター

干305-8568 茨城県つくば市梅園 1-1-1

Tel: 029-861-5449

E-mail: takashi.oozeki@aist.go.jp

\title{
電気学会発行図書
}

New! 電気電子系学生のための英語処方

一論文執筆から口頭発表のテクニックまでー

\begin{abstract}
馬場 吉弘、監修 William A. Chisholm
本書は, 電気電子工学分野の学生のための英語論文執筆·発表ガイドブックです。 第1章は執筆法を説明し、能動態と受動態の使い方, 時制の選び方, 助動詞の使い 方, 冠詞の選び方などについても詳述しています。第2章は口頭発表法を説明し、グ ラフや表の説明法, 数や数式の読み方, 質問への対処法などについても触れていま す。第 3 章は電気電子工学の各分野における英文教科書や学術論文に記載されて いる文章を引用し, 役立つ諸表現の実例を和訳とともに示しています。付録では, 論 文投稿の手続き, 電子メールの文例, 留学関連の手続きなどを紹介しています。ま た本書は, 15 回からなる大学講義で教科書や参考書として利用しやすいようにも工 夫され、企業での技術者研修にも有用です。学生のみならず技術者·研究者も必携 の英語ガイ゙です。

《目次》: 第 1 章 英語論文執筆法(英語論文の構成 $/$ 能動態と受動態の使い方 $/$ 時 制の選び方/助動詞の使い方/不定冠詞之定冠詞の使い方/接続詞·分詞構文.

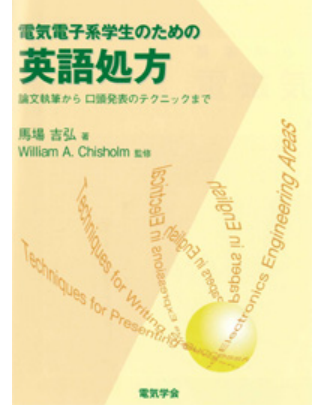
関係代名詞の使い方/ハイフン・ダッシュ・コロン·セミコロンの使い方)、第2章 英語論文口頭発表法(発表用スライドの 作成方と発表法/グラフや表の説明法／数と数式の読み方／質問への対処法／国際会議での座長のことば／発表用 ポスターの作成法と発表法)、第3章 電気電子工学分野によける諸表現(電気磁気学における表現/電気回路理論に おける表現／電力・エネルギー分野における表現／電子デバイスに関する表現／情報通信に関する表現)、付録(論文 投稿から掲載または発表にいたるまでの流れ／インパクトフアクタについて／電子メール文例／アメ为学関連手続き /電気学会雑誌に掲載された英語論文執筆·発表法に関する文献リス卜）

B5 判/並製/248 頁/定価 2,625 円/会員特価 2,100 円

ホームページまたはe-mail, faxなどでご注文ください。税込表示, 送料400円〜

一般社団法人電気学会 編修出版課 http://www.iee.or.jp e-mail : pub@iee.or.jp FAX: 03-3221-3704
\end{abstract}

